\title{
Age-related decomposition of Quercus mongolica branches
}

\author{
Hee Myung Chae $\cdot$ Sangsub Cha $\cdot$ \\ Sang Hoon Lee • Moon Jong Choi · Jae Kuk Shim
}

Received: 12 August 2015/Accepted: 23 May 2016/Published online: 2 June 2016

(C) The Author(s) 2016. This article is published with open access at Springerlink.com

\begin{abstract}
Litter decomposition is a critical process for the maintenance of terrestrial ecosystems. Although large quantities of organic matter and nutrients are supplied by branch litter, its decomposition has received little attention. In this study, we focused on Quercus mongolica, one of the most common temperate deciduous woody species in the Northern Hemisphere, to investigate the age-related decomposition rate of branches. Branches of different age classes $(2,4,7,10$, and 13 years), downed after a summer windstorm, were collected, and mass loss was measured over 24 months using the litterbag method. Litterbag samples were retrieved every 4 months and analyzed for dry weight, carbon (C), nitrogen (N), lignin, and cellulose concentration, and also two litter quality indices $(\mathrm{C} / \mathrm{N}$ and lignin/ $\mathrm{N})$ were calculated. Mass loss by decomposition was significantly faster in 2-year-old branches $(34.78 \%)$ than in 13-year-old branches $(25.71 \%)$. Branch decomposition showed a negative relationship with the initial $\mathrm{C}$ concentration, $\mathrm{C} / \mathrm{N}$, and lignin/ $\mathrm{N}$, but a positive relationship with the initial lignin and $\mathrm{N}$ concentrations. The decomposition rate differed significantly between different branch
\end{abstract}

Communicated by William E. Rogers.

H. M. Chae - S. Cha - S. H. Lee - M. J. Choi ·

J. K. Shim $(\bowtie)$

Department of Life Science, Chung-Ang University,

Seoul 156-756, Korea

e-mail: shimjk@cau.ac.kr age classes and initial litter qualities and was strongly influenced by the initial $\mathrm{N}$ concentration and $\mathrm{C} / \mathrm{N}$. Overall, the results showed that total $\mathrm{N}$ and $\mathrm{C} / \mathrm{N}$ might be the key factors in the decomposition of $Q$. mongolica woody materials, and they could be used as predictive indices of branch decomposition in future studies.

Keywords Branch age - Wood decomposition · Chemical composition · Nitrogen and lignin · Quercus mongolica

\section{Introduction}

Wood species are a major fraction of net primary production and biomass and, thus, are considered a nutrient reservoir and important component of the carbon (C) pool in forest ecosystems (Harmon et al. 1986; Bargali 1996; Chen et al. 2005). Wood debris on the forest floor increases habitat diversity and enhances seedling survival and growth (Abbott and Crossley 1982; Freedman et al. 1996; Ganjegunte et al. 2004). In addition, woody litter decomposition considerably influences carbon dynamics in forest ecosystems (Upadhyay and Singh 1985; Yatskov et al. 2003). Therefore, more information is needed on woody litter decomposition in order to better understand the basic functions of forest ecosystems and make better forest management decisions (Tuomi et al. 2011). 
Although the amount of branch litter, which is fine woody debris typically $<10 \mathrm{~cm}$ in diameter, is much smaller than that of foliar litter (Laiho et al. 2003), the former may be of great importance regarding $\mathrm{C}$ cycling and storage in forest ecosystems (Vávřová et al. 2009). Bray and Gorham (1964) suggested that branch litter comprises approximately $30 \%$ of total litterfall in temperate forests and acts as a long-term nutrient reservoir that releases nutrients slowly and influences nutrient dynamics (Harmon et al. 1986). Despite the importance of branch litter, little is known about the decomposition dynamics of this material (Fasth et al. 2011), whereas no information is available on the relationship between branch age and decomposition rate. Litter chemical composition, defined as substrate quality, debris type and size, and litter age (Harmon et al. 1986) are considered highly important factors in the determination of decomposition rates (Ganjegunte et al. 2004; Ge et al. 2013). Lignin is an abundant component of litter that reduces the decomposition rate of woody debris (Upadhyay and Singh 1985; Ganjegunte et al. 2004; Fioretto et al. 2005; Garrett et al. 2010). Total nitrogen (N), C/N, and lignin/ $\mathrm{N}$ are considered good factors for predicting the decomposition rate of litter (Melillo et al. 1982; Berg and Ekbohm 1991; Bargali 1996).

The Mongolian oak (Quercus mongolica Fischer ex Ledebour), which is mainly distributed in Korea, North China, Northeast China, Japan, and parts of Russia (Zhang 2000), is the dominant plant species in the temperate deciduous forests of the cool temperate forest zone of Korea (Yim 1977; Yim and Baik 1985). Additionally, Quercus species (Fagaceae), including Q. mongolica, are the most common woody plants in the Northern Hemisphere (Manos et al. 1999). Therefore, it is very important to understand the ecological functions within the $Q$. mongolica forests of Northeast Asia. Previous studies have investigated the decomposition of Quercus litter (Abbott and Crossley 1982; Upadhyay and Singh 1985; Mun 2004; Li et al. 2009; Osono et al. 2014); however, little is known about the pattern of age-related changes in nutrient concentration and the decomposition rate of branch litter.

In this study, we aimed to determine the decomposition rates of newly downed branches of different age classes $(2,4,7,10$, and 13 years) collected in $Q$. mongolica-dominated temperate deciduous forests. We hypothesized that the initial chemical quality and branch age affected the decomposition rate of branches, and that the initial chemical quality and decomposition rate would decrease with branch age. To test these hypotheses, we examined the relationships between branch age and chemical composition, decomposition rate, and nutrient dynamics over a decomposition period of 24 months.

\section{Materials and methods}

Study site

In the present study, we performed a decomposition experiment in a $Q$. mongolica forest at Mt. Jumbong $\left(38^{\circ} 02^{\prime} 35^{\prime \prime} \mathrm{N}, 128^{\circ} 25^{\prime} 40^{\prime \prime} \mathrm{E}\right.$; peak elevation $1424 \mathrm{~m}$ above sea level), a Long Term Ecological Research site in the southern part of the Seorak National Park. Q. mongolica accounts for $46.3 \%\left(6787 \mathrm{~km}^{2}\right)$ of the total deciduous broad-leaved forest area $\left(14,663 \mathrm{~km}^{2}\right)$ in South Korea (Yang 2001). In 1982, Mt. Jumbong and Mt. Seorak were the first sites in Korea that designated biosphere reserves by the UNESCO's Man and the Biosphere (MAB) project. The Jumbong Long Term Ecological Research site includes three permanent plots $(100 \mathrm{~m} \times 100 \mathrm{~m}$ each $)$ that are individually dominated by $Q$. mongolica, Abies holophylla, and Pinus densiflora. Each permanent plot is divided into 25 subplots $(20 \mathrm{~m} \times 20 \mathrm{~m}$ each $)$.

This study was performed in the $Q$. mongolicadominated permanent plot, in which $Q$. mongolica is usually mixed with $Q$. serrata and Fraxinus rhynchophylla in the tree layer; Acer pseudosieboldianum, Rhododendron schlippenbachii, Symplocos chinensis, F. rhynchophylla, Lindera obtusiloba, Lespedeza maximowiczii, and Magnolia sieboldii in the sub-tree layer and shrub layer; and Syneilesis palmata, Sasa borealis, L. maximowiczii, and Carex siderosticta in the herb layer (Yim and Baik 1985). The coverage of the tree layer is $80-90 \%$, that of the shrub layer is $40-55 \%$, and that of the herb layer is 40-80\%.

From 1980 to 2010, the average annual temperature at the Inje meteorological station $(14.6 \mathrm{~km}$ from the study site, elevation $200 \mathrm{~m}$ above sea level) was $10.7^{\circ} \mathrm{C}$, and the annual precipitation was $1170 \mathrm{~mm}$. During summer (June through August), the average monthly temperature was $20.0-23.3^{\circ} \mathrm{C}$, and the monthly precipitation was $118-307 \mathrm{~mm}$. During winter (December through February), the average 
monthly temperature was -2.0 to $-5.2{ }^{\circ} \mathrm{C}$, and the monthly precipitation was $18-21 \mathrm{~mm}$.

In September 2011, four soil sample cores were collected at random from the $0-20-\mathrm{cm}$ layer in the $Q$. mongolica-dominated permanent plot and ignited in a muffle furnace at $550{ }^{\circ} \mathrm{C}$ for $12 \mathrm{~h}$. The $\mathrm{pH}$ was measured using a Corning 345 digital $\mathrm{pH}$ meter (Corning Inc., Corning, NY, USA). Calcium (Ca), phosphorus $(\mathrm{P})$, potassium $(\mathrm{K})$, and magnesium $(\mathrm{Mg})$ concentrations were determined with a JY-ULTIMA2 inductively coupled plasma spectrometer (JobinYvon, Longjumeau, France). The soil at the study site had a high clay content, slight acidity, and low soil organic matter content, and contained $687 \mathrm{mg} \mathrm{kg}^{-1}$ $\mathrm{Ca}, 146 \mathrm{mg} \mathrm{kg}^{-1} \mathrm{P}, 1499 \mathrm{mg} \mathrm{kg}^{-1} \mathrm{~K}, \quad$ and $2686 \mathrm{mg} \mathrm{kg}^{-1} \mathrm{Mg}$ (Table 1).

Experimental design

A class interval of three years was chosen to determine the differences between the decomposition rates of 2to 13-year-old branches over a decomposition period of 24 months. One-year-old branches were excluded, since they did not conclude a full growing season. In September 2011, samples of 2-, 4-, 7-, 10-, and 13 -year-old branches were collected from the southfacing slopes of $Q$. mongolica-dominated forest adjacent to the permanent plot and obtained from newly downed $Q$. mongolica specimens (diameter at breast height $>30 \mathrm{~cm}$ ), with no signs of decay, immediately after a summer windstorm (Bargali 1996). Branch age was determined by counting the internodes from the tip of each branch (Li et al. 2009) and measuring the diameter of each branch with a micrometer. The branches were cut into $4-\mathrm{cm}$-long pieces and dried at $60{ }^{\circ} \mathrm{C}$ to a constant mass. Dried woody samples $(10 \mathrm{~g}$ each) were placed into $10 \mathrm{~cm} \times 10 \mathrm{~cm}$ litterbags made of polyvinyl chloride-coated fiberglass (mesh size $2 \mathrm{~mm}$ ) along with an aluminum identification tag. One hundred twenty litterbags were prepared and four forest floor plots were selected randomly to place litterbags. Four plots $(10 \mathrm{~m} \times 10 \mathrm{~m}$ each $)$ were arranged in a transect and spaced $50-100 \mathrm{~m}$ apart in the $Q$. mongolica-dominated forest. We selected plots with similar slope and elevation in order to minimize the impact of other environmental factors. In each plot, 30 litterbags (six litterbags per branch age class) were placed on the forest floor surface in December 2011. The sampling of litterbags occurred six times every four months over a decomposition period of 24 months. At each sampling, 20 litterbags (four litterbags per branch age class) were randomly retrieved from the four plots (five litterbags per plot) for analysis.

Mass loss measurements

Litterbags retrieved from the experimental site were transported to the laboratory and kept at $-20{ }^{\circ} \mathrm{C}$ until further processing. Soil or roots that penetrated into the litterbags were carefully removed, and wood samples were dried at $60{ }^{\circ} \mathrm{C}$ to a constant mass.

The remaining mass was determined as the percentage of retrieved dry mass to initial mass prior to decomposition. The decomposition coefficient $k$ was calculated by non-linear regression based on the single exponential decomposition model as follows (Olson 1963):

$X_{t}=X_{o} e^{-k t}$,

where $X_{t}$ is the mass at time $t$ and $X_{o}$ is the initial mass.

Litter half-life $\left(t_{0.5}\right)$, which is the time necessary to reach $50 \%$ mass loss, was estimated as follows (Olson 1963):

Table 1 Physical and chemical properties of soil at Mt. Jumbong, Seorak National Park, Korea, in September 2011

\begin{tabular}{|c|c|c|c|c|c|c|c|c|c|}
\hline & \multirow[t]{2}{*}{ SOM (\%) } & \multirow[t]{2}{*}{$\mathrm{pH}$} & \multicolumn{3}{|c|}{ Soil texture } & \multicolumn{4}{|c|}{ Mineral nutrient content $\left(\mathrm{mg} \mathrm{kg}^{-1}\right.$ soil) } \\
\hline & & & Sand $(\%)$ & Silt (\%) & Clay (\%) & $\mathrm{Ca}$ & $\mathrm{P}$ & $\mathrm{K}$ & $\mathrm{Mg}$ \\
\hline Mean & 11.9 & 4.6 & 27.8 & 19.4 & 52.8 & 686.8 & 146.2 & 1498.9 & 2685.8 \\
\hline $\mathrm{SD}( \pm)$ & 1.2 & 0.04 & & & & 71.4 & 21.3 & 135.8 & 395.8 \\
\hline
\end{tabular}

Mean, average value of four soil samples

$S D$ standard deviation, $S O M$ soil organic matter, $C a$ calcium, $P$ phosphorus, $K$ potassium, $M g$ magnesium 
$t_{0.5}=-\ln (0.5) /(k)=0.693 / k$.

Chemical analysis

The dried wood samples were pulverized using a Wiley mill (Thomas Scientific, Swedesboro, NJ, USA) with a $0.1-\mathrm{mm}$ mesh. Subsequently, $0.5 \mathrm{~g}$ pulverized samples were used for determining organic $\mathrm{C}$, total $\mathrm{N}$, lignin, cellulose, and ash contents. The concentration of organic $\mathrm{C}$ was measured using the dichromate wet oxidation method as described by Nelson and Sommers (1996). Total N was determined by the Kjeldahl method (Bremner 1996) using a Tecator digestion system (FOSS, Hillerod, Denmark) and a Kjeltec 8100 distillation apparatus (FOSS). Lignin and cellulose were determined using the acid detergent fiber method as described by Rowland and Roberts (1994). Ash content was determined by ignition at $550{ }^{\circ} \mathrm{C}$ for $4 \mathrm{~h}$.

\section{Statistical analysis}

One-way analysis of variance (ANOVA), followed by Duncan's new multiple range test, was used to identify significant differences $(p<0.05)$ in the initial chemical concentrations among the branch age classes. Correlation analysis was performed to identify relationships among branch age class, initial chemical components $(\mathrm{C}, \mathrm{N}$, lignin, cellulose, $\mathrm{C} / \mathrm{N}$, and lignin/ $\mathrm{N}$ ), and mass loss. Regression slopes of changes in chemical components and mass loss in relation to branch age class were determined. Intercepts $(a)$ and slopes $(b)$ of regression equations were calculated for the linear relationship using least-squares regression, and the slope of $\mathrm{N}$ dynamics was named $\mathrm{N}$ concentration increase rate (NCIR; Berg et al. 1997). All statistical analyses were conducted using SPSS 17.0 (IBM SPSS Inc., Chicago, IL, USA). Additionally, we used nonmetric multidimensional scaling (NMDS) to examine the relationships between decomposing branches of different age classes and initial litter quality using meta-multidimensional scaling and envfit functions in the Vegan library of R 2.15.3 (R Development Core Team; http://cran.r-project.org).

\section{Results}

Initial chemical composition

The diameter and initial chemical composition of $Q$. mongolica branches at different age classes are presented in Table 2. The mean diameter of 2-, 4-, 7-, 10-, and 13-year-old Q. mongolica branches were $3.63,5.43,6.75,10.28$, and $14.45 \mathrm{~mm}$, respectively. Total $\mathrm{C}$ concentration was the lowest in 2-year-old branches (44.2\% of dry mass), but did not differ significantly between age classes (44.2-44.7\% of dry mass). Total $\mathrm{N}$ concentration decreased with branch age and ranged between $0.27 \%$ of dry mass in 10- and 13-year-old branches and $0.44 \%$ of dry mass in 2-year-old branches. Lignin concentration was the highest in 2-year-old branches (23.5\% of dry mass) and decreased with branch age, ranging between $18.3 \%$ in 13-year-old branches and $19.8 \%$ in 4-yearold branches. Cellulose concentration increased with branch age and ranged between $34.0 \%$ of dry mass in 2-year-old branches and $45.2 \%$ of dry mass in 13-year-old branches. Ash content decreased with branch age and ranged between $0.75 \%$ of dry mass in 10- and 13-year-old branches and $1.80 \%$ of dry mass in 2-year-old branches. $\mathrm{C} / \mathrm{N}$ and lignin/ $\mathrm{N}$ showed linear relationships with branch age. $\mathrm{C} / \mathrm{N}$ was the lowest in 2-year-old branches (101.3) and the highest in 13-year-old branches (168.3), whereas lignin/ $\mathrm{N}$ was the lowest in 2-year-old branches (58.8) and the highest in 10-year-old branches (72.9) (Fig. 1).

Mass loss and decomposition rates

After 24 months of decomposition, the mass of 2-yearold branches reduced by $34.8 \%$ of the initial mass, of 4-year-old branches by $29.6 \%$ of the initial mass, of 7-year-old branches by $29.2 \%$ of the initial mass, of 10 -year-old branches by $28.2 \%$ of the initial mass, and of 13 -year-old branches by $25.7 \%$ of the initial mass (Fig. 2). Mass loss decreased with branch age during the decomposition period $\left(R^{2}=0.816, p<0.05\right.$; Fig. 3). Decomposition rates decreased with branch age, and the decomposition coefficients $k$ ranged between 0.159 in 2-year-old branches and 0.217 in 13-year-old branches (Table 3; Fig. 3). Litter half-life ranged between 3.2 years in 2-year-old branches and 4.4 years in 13 -year-old branches (Table 3 ). 
Table 2 Initial chemical composition of Quercus mongolica branches in different age classes (2, 4, 7, 10, and 13 years)

\begin{tabular}{lccccc}
\hline \multicolumn{7}{c}{ Branch age class (years) } & & & \\
\cline { 2 - 6 } & 2 & 4 & 7 & 10 & 13 \\
\hline Diameter (mm) & $3.63 \pm 1.14$ & $5.43 \pm 1.85$ & $6.75 \pm 2.52$ & $10.28 \pm 3.27$ & $14.45 \pm 3.87$ \\
Carbon (\%) & $44.2 \pm 0.3 \mathrm{a}$ & $44.6 \pm 0.1 \mathrm{~b}$ & $44.5 \pm 0.1 \mathrm{~b}$ & $44.5 \pm 0.2 \mathrm{~b}$ & $44.7 \pm 0.0 \mathrm{~b}$ \\
Nitrogen (\%) & $0.44 \pm 0.02 \mathrm{a}$ & $0.34 \pm 0.01 \mathrm{~b}$ & $0.30 \pm 0.01 \mathrm{c}$ & $0.27 \pm 0.01 \mathrm{~d}$ & $0.27 \pm 0.00 \mathrm{~d}$ \\
Lignin (\%) & $23.5 \pm 2.1 \mathrm{a}$ & $19.8 \pm 0.3 \mathrm{~b}$ & $19.1 \pm 0.7 \mathrm{~b}$ & $19.7 \pm 0.1 \mathrm{~b}$ & $18.3 \pm 0.8 \mathrm{~b}$ \\
Cellulose (\%) & $34.0 \pm 2.9 \mathrm{a}$ & $42.0 \pm 0.4 \mathrm{ab}$ & $43.3 \pm 0.1 \mathrm{ab}$ & $46.8 \pm 0.0 \mathrm{~b}$ & $45.2 \pm 1.1 \mathrm{c}$ \\
Ash (\%) & $1.80 \pm 0.67 \mathrm{a}$ & $0.90 \pm 0.20 \mathrm{~b}$ & $1.15 \pm 0.19 \mathrm{~b}$ & $0.75 \pm 0.41 \mathrm{~b}$ & $0.75 \pm 0.10 \mathrm{~b}$ \\
Carbon/nitrogen & $101.3 \pm 5.1 \mathrm{a}$ & $130.2 \pm 3.2 \mathrm{~b}$ & $148.3 \pm 2.1 \mathrm{c}$ & $165.2 \pm 1.0 \mathrm{~d}$ & $168.3 \pm 4.4 \mathrm{~d}$ \\
Lignin/nitrogen & $58.8 \pm 5.1 \mathrm{a}$ & $57.7 \pm 0.8 \mathrm{a}$ & $63.6 \pm 2.5 \mathrm{~b}$ & $72.9 \pm 2.7 \mathrm{c}$ & $68.8 \pm 2.8 \mathrm{c}$ \\
\hline
\end{tabular}

Values are means $(n=4)$ and $\pm \mathrm{SD}$

Different lowercase letters in the same row indicate differences at $p<0.001$ (Duncan's new multiple range test)

Fig. 1 Relationships between initial a carbon/ nitrogen $(\mathrm{C} / \mathrm{N})$ and $\mathbf{b}$ lignin/ nitrogen $($ lignin/ $\mathrm{N})$ and different age classes $(2,4,7$, 10 , and 13 years) of Quercus mongolica branches $(n=5)$
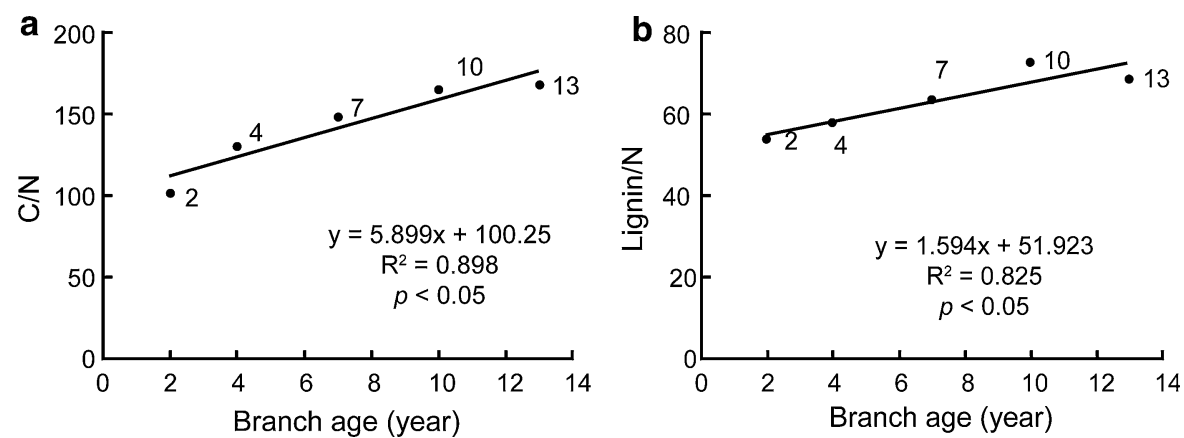

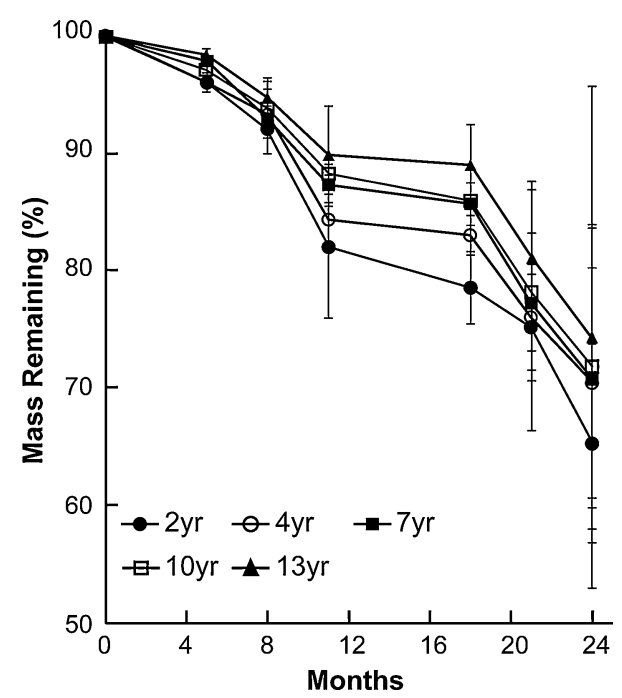

Fig. 2 Changes in mass of Quercus mongolica branches in different age classes $(2,4,7,10$, and 13 years) during a decomposition period of 24 months. Bars indicate SD $(n=4)$

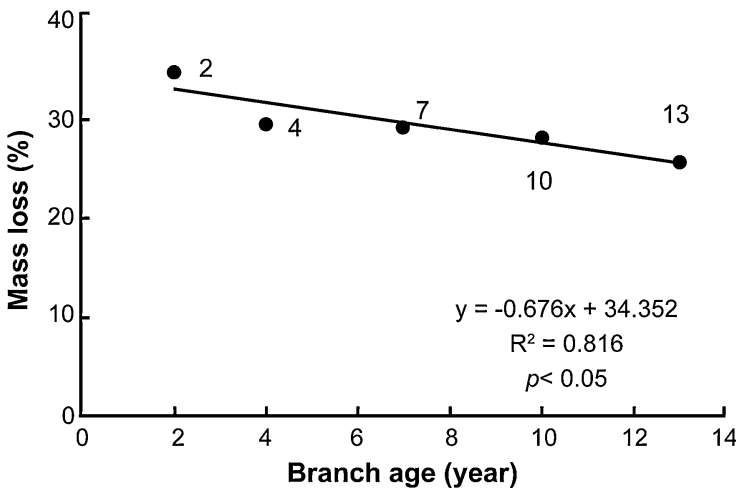

Fig. 3 Relationship between mass loss and different age classes $(2,4,7,10$, and 13 years) of Quercus mongolica branches during a decomposition period of 24 months $(n=5)$. Numbers near each black circle indicate branch age 
Table 3 Decomposition coefficient $k$ and half-life (50\% decomposition) of Quercus mongolica branches in different age classes (2, $4,7,10$, and 13 years) after a decomposition period of 24 months

\begin{tabular}{llllll}
\hline Parameters & \multicolumn{4}{l}{ Branch age class (years) } \\
\cline { 2 - 5 } & 2 & 4 & 7 & 10 & 13 \\
\hline Decomposition coefficient $k$ & 0.217 & 0.179 & 0.179 & 0.171 \\
Half-life (years) & 3.2 & 3.9 & 3.9 & 4.1 & 4.4 \\
\hline
\end{tabular}

Half-life was calculated as described by Olson (1963)

Changes in litter chemical composition during decomposition

In decomposing branches, $\mathrm{C}$ concentration showed a similar pattern with mass loss (Fig. 4a), whereas $\mathrm{N}$ concentration increased by immobilization (Fig. 4b). Significant immobilization of $\mathrm{N}$ occurred during the summer, due to high humidity and air temperature. Total $\mathrm{N}$ concentration showed a different increase rate (as determined by the regression slope) in different branch age classes during decomposition (Fig. 4b). The increase in total $\mathrm{N}$ concentration was positively correlated with branch age (Fig. 5a); thus, it was the fastest in the 13-year-old branches. The amount of remaining cellulose decreased after a year, whereas the amount of remaining lignin remained stable throughout the decomposition period (Fig. 4c, d). Both $\mathrm{C} / \mathrm{N}$ and lignin/ $\mathrm{N}$ showed similar patterns and gradually decreased during the decomposition period (Fig. 4e, f). The decrease rate of $\mathrm{C} / \mathrm{N}$ and lignin/ $\mathrm{N}$ was the slowest in 2-year-old branches and the fastest in the 13-year-old branches; therefore, it showed a significant negative relationship with branch age (Fig. 5b, c).

Decomposition rate and litter qualities

The rate of branch decomposition decreased with branch age and was positively correlated with the initial total $\mathrm{N}$ and lignin concentrations. However, the initial $\mathrm{C}$ and cellulose concentrations and the initial $\mathrm{C} / \mathrm{N}$ and lignin/ $\mathrm{N}$ were negatively correlated with the rate of litter decomposition (Fig. 6). The 2-year-old branches had the highest lignin and $\mathrm{N}$ concentrations and showed the most rapid decomposition rate (Table 2; Fig. 2). Additionally, branch diameter, surface area, and volume were significantly positively correlated with branch age, but did not show any significant relationship with mass loss (Table 4).
NMDS analysis showed that each branch age class was clearly distinguished by differences in mass loss, which was more strongly correlated with total $\mathrm{N}$ and $\mathrm{C} / \mathrm{N}$ than the other litter qualities (Fig. 7). Total $\mathrm{N}$ showed a strong positive correlation with mass loss in each branch age class during the decomposition period, whereas $\mathrm{C} / \mathrm{N}$ showed a strong negative correlation with mass loss (Fig. 6). Moreover, lignin/ $\mathrm{N}$ had a less explanatory power for the decomposition rate than lignin (Figs. 6, 7).

\section{Discussion}

Variation in chemical composition in relation to branch age

Our study showed that $\mathrm{N}$, cellulose, and lignin concentrations as well as $\mathrm{C} / \mathrm{N}$ and lignin/ $\mathrm{N}$ differed significantly among the branch age classes. Tree branches are composed of tissues of different ages; therefore, the nutrient contents are not evenly distributed and are lower in older tissues (Li et al. 2009). In general, $\mathrm{N}$ concentration is high in the actively growing parts of the trees and low in the structural parts that are not actively growing. Our results showed that $\mathrm{N}$ decreased significantly with branch age ( $\mathrm{Li}$ et al. 2009), whereas cellulose concentration increased with branch age (Ona et al. 1997; Ohshima et al. 2005).

Lignin concentration was high in 2-year-old branches of $Q$. mongolica, and it decreased with branch age. Bao et al. (2001) and Ona et al. (1997) reported that young wood has a higher lignin concentration than mature wood, and that lignin concentration naturally decreases with age and the increasing mature wood volume. In this study, lignin concentration in different age classes was significantly positively correlated with $\mathrm{N}$ concentration $\left(R^{2}=0.957\right.$, 


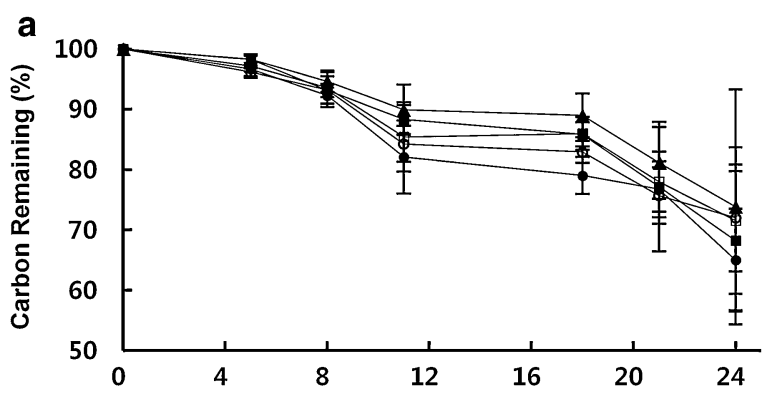

b
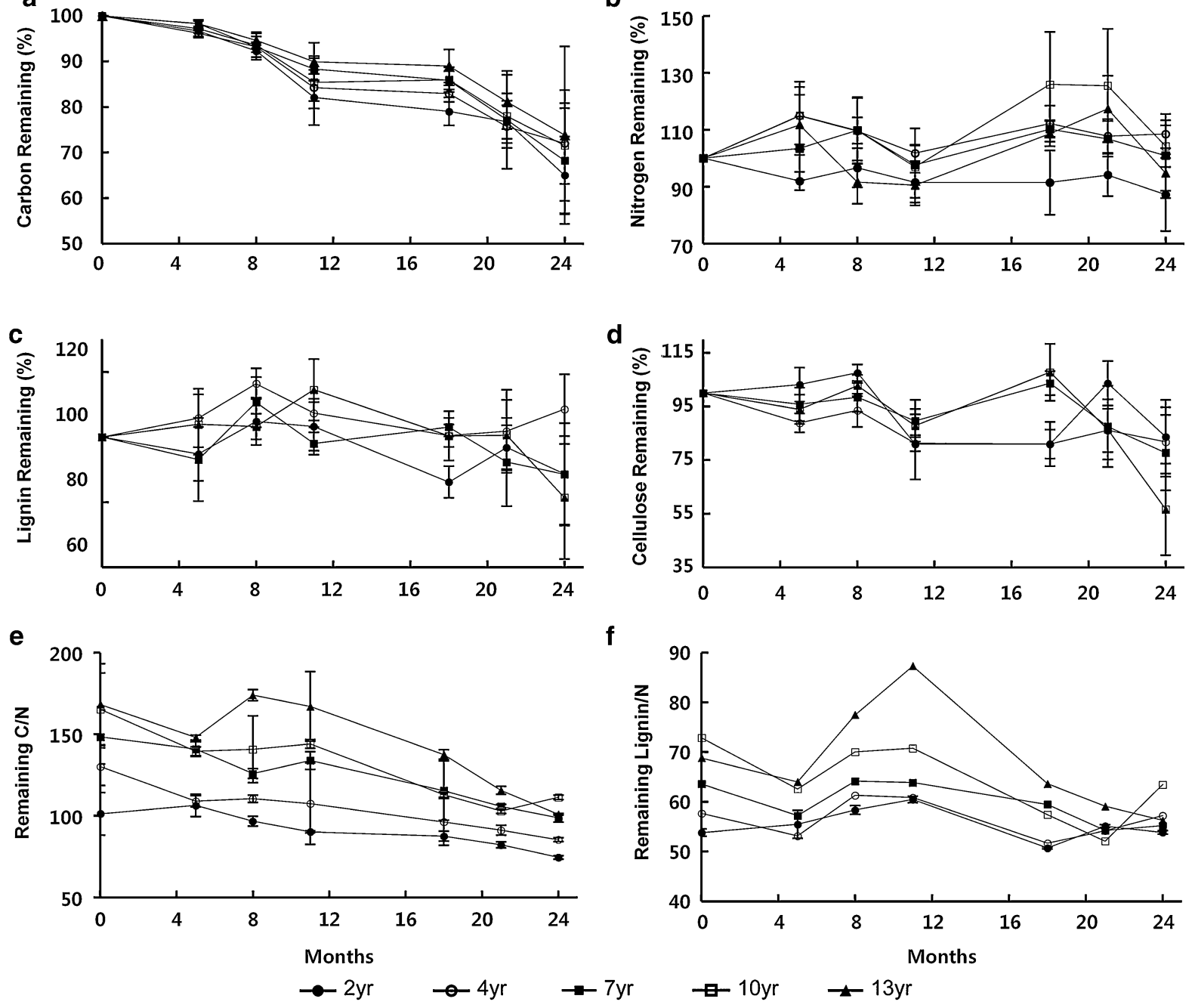

Fig. 4 Changes in remaining a carbon (C), b nitrogen (N), c lignin, d cellulose, e carbon/nitrogen $(\mathrm{C} / \mathrm{N})$, and $\mathbf{f}$ lignin/ nitrogen (lignin/ $\mathrm{N}$ ) of Quercus mongolica branches in different

$p<0.001$ ), whereas the lowest lignin/ $\mathrm{N}$ was found in 2-year-old branches (Fig. 1b). Li et al. (2009) found that $\mathrm{C}$ concentration was independent of age in 1- to 4-year-old $Q$. aquifolioides branches. However, they found that $\mathrm{N}$ concentration significantly decreased, whereas $\mathrm{C} / \mathrm{N}$ significantly increased with branch age, results that were in agreement with those obtained in this study (Table 2; Fig. 1a).

Mass loss and nutrient dynamics in different branch age classes

Our data showed that mass loss decreased with the increasing branch age class, and that changes in the d

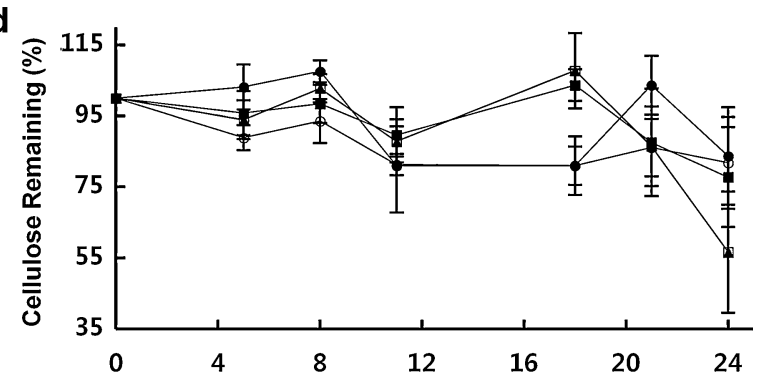

f

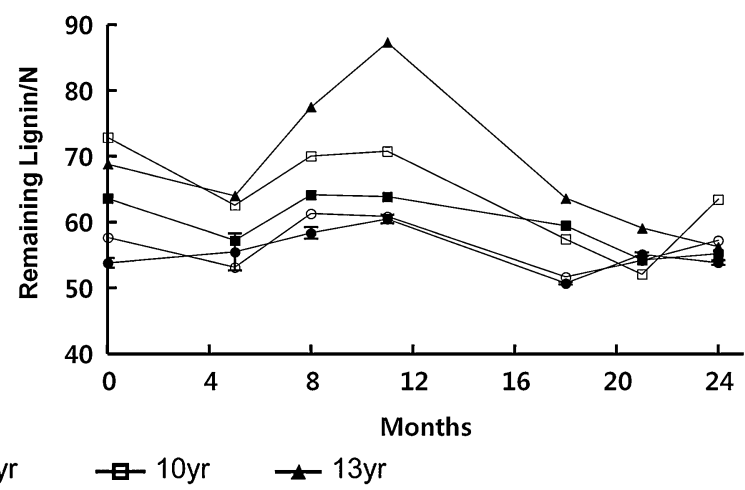

age classes $(2,4,7,10$, and 13 years) during a decomposition period of 24 months $(n=4)$

chemical composition varied individually during decomposition. Nitrogen concentration increased in all branch age classes, except for 2-year-old branches, lignin remained stable, and cellulose fluctuated with season and started to decrease after a decomposition period of 21 months. Many studies have focused on leaf litter because of its high importance in forest ecosystems (Berg and McClaugherty 2008). The annual input of branch litter accounts for a substantial percentage of the total annual litter production and plays an important role in the dynamics of temperate forests (Harmon et al. 1986). Litter production from branches accounts for approximately $12-22 \%$ of total litterfall in temperate Quercus forests (Bray and 

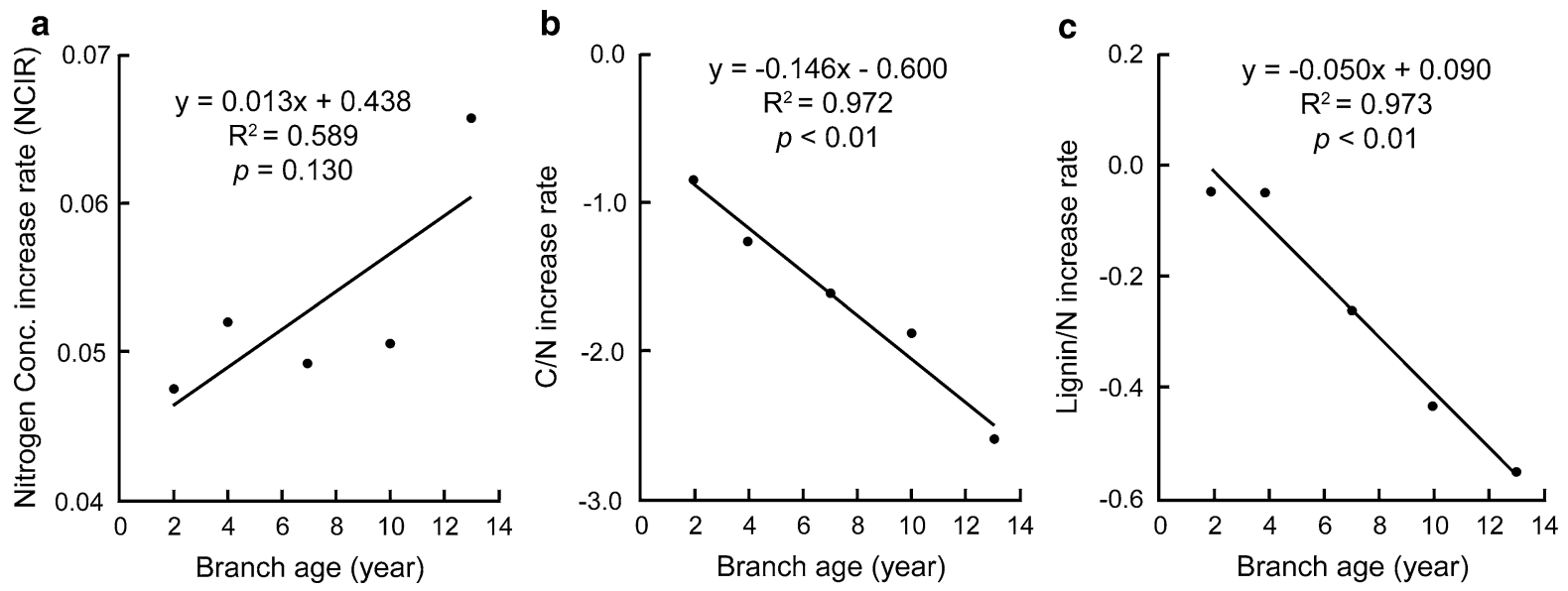

Fig. 5 Relationships between a total nitrogen $(\mathrm{N})$, b carbon/nitrogen $(\mathrm{C} / \mathrm{N})$, and $\mathbf{c}$ lignin/nitrogen (lignin/N) increase rate and different age classes $(2,4,7,10$, and 13 years) of Quercus mongolica branches during a decomposition period of 24 months $(n=5)$

Fig. 6 Relationships between mass loss of Quercus mongolica branches in different age classes $(2,4,7,10$, and 13 years) and initial litter quality parameters (carbon [C], nitrogen [N], lignin, and cellulose concentrations, carbon/nitrogen $[\mathrm{C} / \mathrm{N}]$, and lignin/nitrogen [lignin/N]) during a decomposition period of 24 months $(n=5)$. Numbers near each black circle indicate branch age
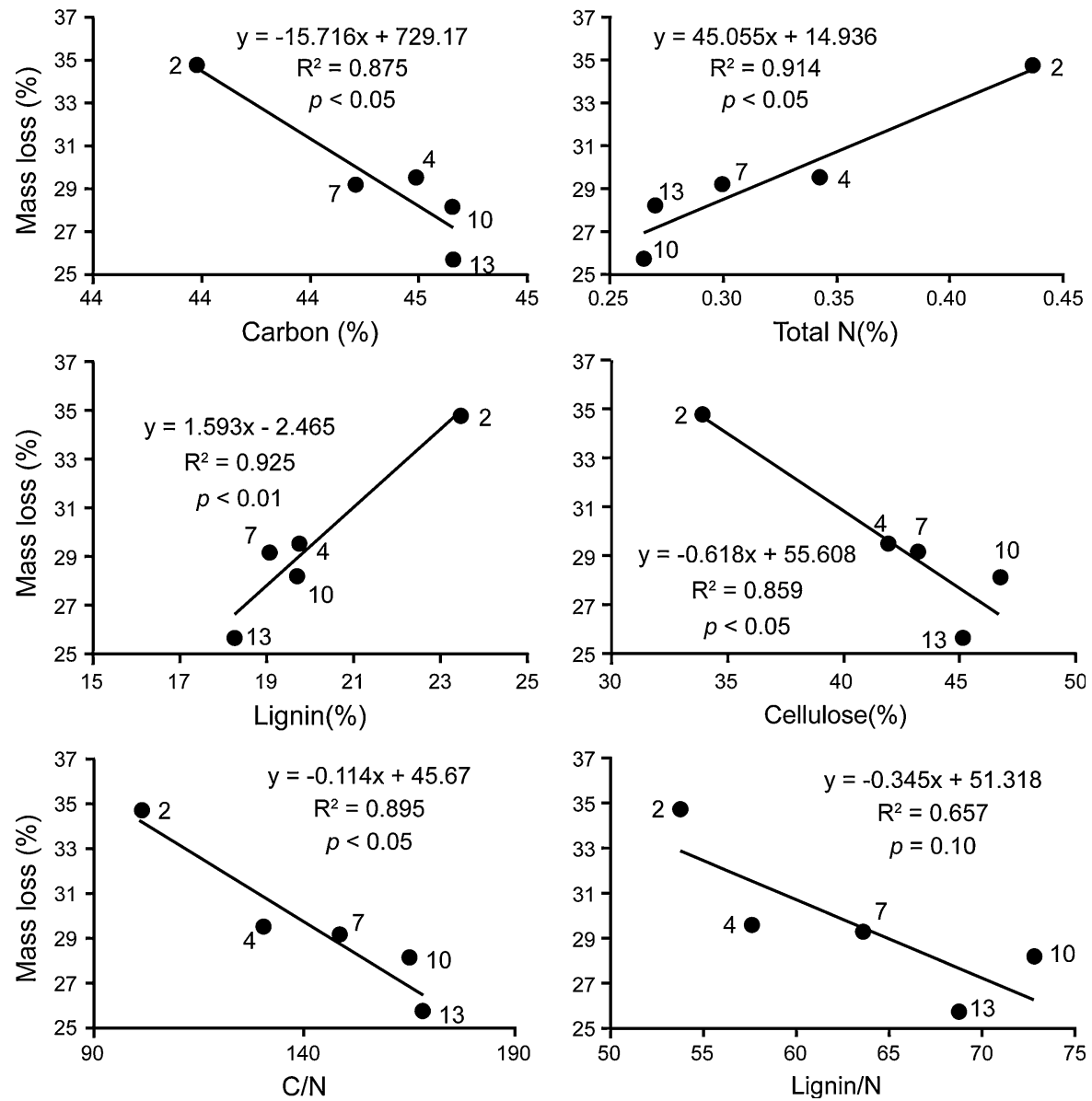
Table 4 Linear regression between mass loss, branch age class, and initial branch physical factors (diameter, surface area, and volume) during a decomposition period of 24 months $(n=5)$

\begin{tabular}{|c|c|c|c|c|c|c|}
\hline & \multicolumn{3}{|c|}{ Branch age class } & \multicolumn{3}{|c|}{ Decomposition rate } \\
\hline & $R^{2}$ & $m$ & $p$ & $R^{2}$ & $m$ & $p$ \\
\hline Branch diameter (mm) & 0.964 & 0.952 & 0.003 & 0.770 & -0.686 & 0.051 \\
\hline Branch surface area $\left(\mathrm{mm}^{2}\right)$ & 0.930 & 25.244 & 0.008 & 0.709 & -0.024 & 0.073 \\
\hline Branch volume $\left(\mathrm{mm}^{3}\right)$ & 0.889 & 53.180 & 0.016 & 0.651 & -0.011 & 0.099 \\
\hline
\end{tabular}

$R^{2}$, coefficient of determination; $m$, slope; $p$, level of significance

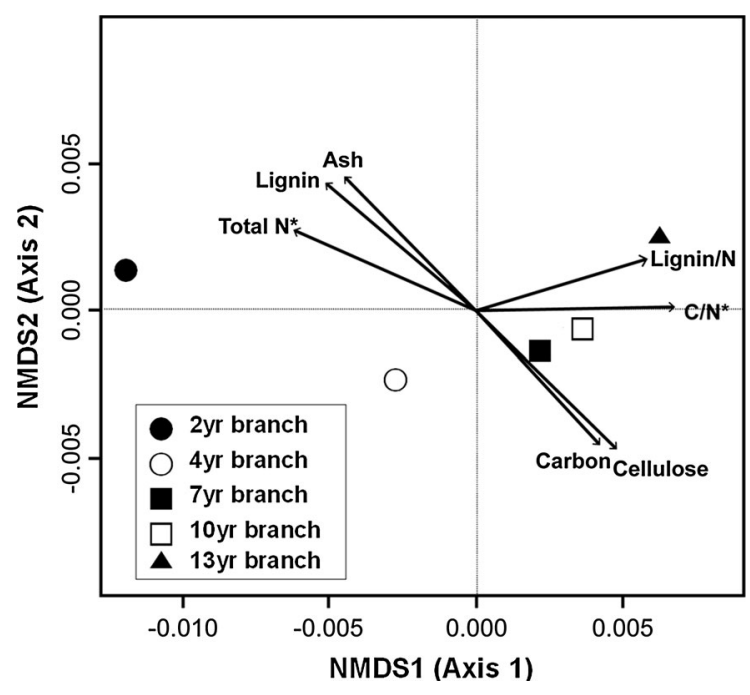

Fig. 7 Non-metric multidimensional scaling (NMDS) ordination between mass loss of Quercus mongolica branches in different age classes $(2,4,7,10$, and 13 years) and initial litter qualities (ash, nitrogen [N], lignin, and cellulose concentrations, carbon/nitrogen $[\mathrm{C} / \mathrm{N}]$, and lignin/nitrogen [lignin/N]) during a decomposition period of 24 months. Arrow direction indicates the correlation slope, and arrow length indicates the strength of the influence of initial litter quality on mass loss $(* p<0.05)$

Gorham 1964; Gosz et al. 1972; Mun 2004; Shin et al. 2011). Nevertheless, only a few studies have examined decomposition in relation to branch age rather than branch thickness (Upadhyay and Singh 1985; Mun 2004; Li et al. 2009).

In this study, the decomposition coefficient $k$ of $Q$. mongolica was 0.159-0.217 across the branch age classes (Table 3), which was slower than the decomposition rate reported in other studies (Abbott and Crossley 1982; Upadhyay and Singh 1985; Mun 2004). Abbott and Crossley (1982) used Quercus prinus branches of $1,1-3$, and $3-5 \mathrm{~cm}$ in diameter and found $k$ values of $0.0377-0.1644$; Upadhyay and Singh (1985) used $Q$. leucotrichophora and $Q$. lanuginose branches of 4.4-5.4 cm in diameter and found $k$ values of $0.334-0.475$; and Mun (2004) used $Q$. acutissima branches of $<1,1-2$, and $3-4 \mathrm{~cm}$ in diameter and found $k$ values of $0.294,0.195$, and 0.215 , respectively. In general, litter decomposition rates are controlled by interacting physical, chemical, and biotic factors (Vávřová et al. 2009). Climate determines the decomposition rates at a regional scale and sets the general limits of decomposition by limiting the activities of decomposition organisms (Heneghan et al. 1999). Previous studies have shown that decomposition varies between species and is affected by physical and regional factors (Abbott and Crossley 1982; Upadhyay and Singh 1985; Mun 2004). The decomposition rate in the present study was lower than that in other studies because of the relatively low mean annual temperature and precipitation. The decomposition rate in our study was partially similar to that obtained by Mun (2004) under similar regional and climatic conditions in a temperate deciduous forest; however, no significant relationship was reported between the decomposition rate and branch diameter.

Colonization time by microbes increases with the increasing size of woody litter (Tuomi et al. 2011). In the present study, branch diameter, surface area, and volume were significantly positively correlated with branch age, and the decomposition of younger branches was faster than that of older branches. However, our results showed that there was no significant relationship between the mass loss and branch physical factors (Table 4), suggesting that other factors, such as the chemical composition of young branches, might be more important for branch decomposition. 
Changes in chemical composition during litter decomposition vary greatly with branch morphology, site condition, season, and climate (Gosz et al. 1973; Abbott and Crossley 1982; Mun 2004). Berg and Matzner (1997) developed a three-stage model (early, late, and third phases) for explaining the decomposition dynamics of chemical composition. In this model, the early phase is regulated by the nutrient level and readily available $\mathrm{C}$; the late phase is regulated by the lignin decomposition rate; and the third phase (final stages) is characterized by a decomposition rate close to zero. In our study, $\mathrm{N}$ increased in all branches age classes, except for 2-year-old branch (Fig. 4b), whereas lignin remained stable throughout the decomposition period (Fig. 4c). The remaining cellulose fluctuated with season and started to decrease after a year in the summer (Fig. 4d). This study showed that mass loss was in the early phase and did not enter the late phase of decomposition, which is regulated by lignin decomposition (Berg and Staaf 1980; Berg and McClaugherty 2008). In the early phase, mass loss in several plant species may be positively related to the concentration of major nutrients such as $\mathrm{N}, \mathrm{P}$, and sulfur (Berg and Ekbohm 1991). Water-soluble substances and non-lignified carbohydrates, including cellulose, decompose after lignin begins to deteriorate and regulate mass loss (Berg and McClaugherty 2008). The late phase starts when a net loss of lignin is observed and, in contrast to the early phase, the increased $\mathrm{N}$ concentration has a decomposition ratesuppressing effect (Berg 2014).

The increase of $\mathrm{N}$ concentration in decaying litter is known as NCIR and shows a linear increase related to the mass loss of several foliar litter types (Berg et al. 1997; Berg and McClaugherty 2008). They found the NCIR ranged between 0.055 and 0.129 , and the litter that contains higher initial $\mathrm{N}$ concentration has larger NCIR. In our study, NCIR ranged between 0.047 and 0.065 (Fig. 5a). However, our results showed that older branches with lower initial $\mathrm{N}$ concentration had higher NCIR than younger branches with higher N concentration, although the differences were not significant ( $p=0.130$; Fig. 5a). This could be attributed to the relatively higher immobilization of $\mathrm{N}$ in the older branches than in those with low initial $\mathrm{N}$ concentration. On the other hand, the regression slopes related to changes in $\mathrm{C} / \mathrm{N}$ and lignin/ $\mathrm{N}$ and mass loss were more significantly correlated with branch age class $(p<0.01)$ than with NCIR. The slopes in each branch age class showed the opposite pattern to $\mathrm{N}$ relationships, because the indices were strongly influenced by the increasing $\mathrm{N}$ concentration and mass loss.

Influence of initial branch litter qualities on branch decomposition

We detected that the decomposition rate was strongly correlated with $\mathrm{N}$ concentration and $\mathrm{C} / \mathrm{N}$ by branch age class. The highest lignin and $\mathrm{N}$ concentrations were identified in 2-year-old branches that had the most rapid decomposition rate. The differences in the decomposition rate among branch age classes can be attributed to differences in the initial chemical composition, since litter quality is an important factor that determines the rates of $\mathrm{C}$ and nutrient turnover from decomposing organic matter (Swift et al. 1976; Heal et al. 1997; Ganjegunte et al. 2004). In particular, $\mathrm{C} / \mathrm{N}$ is accepted as a general quality index for predicting the decomposition rate in a wide spectrum of resource types (Heal et al. 1997). Our results also indicated that branch age classes differed in the initial chemical composition, and that the decomposition rate was significantly correlated with each parameter of litter quality. Cellulose concentration, $\mathrm{C} / \mathrm{N}$, and lignin/ $\mathrm{N}$ were significantly negatively correlated with the decomposition rate, whereas total $\mathrm{N}$ concentration was positively correlated. These results are in agreement with those reported in previous studies (Harmon et al. 1986; Bargali 1996; Ganjegunte et al. 2004; Yang et al. 2010).

The correlation identified between litter decomposition and lignin concentration was in disagreement with previous studies, which reported that a relatively high lignin concentration reduces the rate of decomposition in early and late stages (Melillo et al. 1982; Berg and McClaugherty 2008; Garrett et al. 2010). Particularly, high lignin concentration reduces the rate of decomposition when associated with high $\mathrm{N}$ concentration, because new and stable complexes are formed (Berg and Ekbohm 1991; Coûteaux et al. 1995). Nevertheless, in this study, the youngest branches decomposed faster than the older branches, despite the relatively high lignin and $\mathrm{N}$ concentrations, suggesting that other chemical properties or parameters have a greater effect on the decomposition rate than lignin concentration.

We assumed that the initial $\mathrm{N}$ concentration and initial $\mathrm{C} / \mathrm{N}$ and lignin/ $\mathrm{N}$ might be more significant 
factors than lignin concentration. It is known that the relatively high $\mathrm{N}$ concentration regulates the early stages of decomposition by enhancing the growth of microorganisms that degrade labile compounds and suppress the formation of lignolytic enzymes (Keyser et al. 1978). Many studies have reported that $\mathrm{N}$ concentration has the greatest positive effect on the decomposition rate (Melillo et al. 1982; Berg and Ekbohm 1991; Berg and McClaugherty 2008). Fioretto et al. (2005) attributed the different decomposition rates of Quercus ilex, Myrtus communis, and Cistus incanus to different initial lignin and $\mathrm{N}$ concentrations. In this study, older branches showed higher $\mathrm{N}$ immobilization than younger branches owing to differences in the initial N (Figs. 4b, 5a). Therefore, the higher $\mathrm{N}$ immobilization in older branches leads to low decomposition rates, because of the increased demand of $\mathrm{N}$ by decomposers (Parton et al. 2007) and/ or the formation of nitrous compounds (Berg 1986; Fog 1988; Dijkstra et al. 2004). In our study, the relationships between the age-related mass loss in young branches and initial chemical qualities showed that mass loss was more strongly related to initial $\mathrm{N}$ and $\mathrm{C} / \mathrm{N}$ than to lignin or lignin/ $\mathrm{N}$, as indicated by NMDS ordination (Fig. 7). The strong relationships between the initial qualities $(\mathrm{N}$ and $\mathrm{C} / \mathrm{N}$ ) and branch decomposition were affected by the decomposition stage. Overall, our study showed that mass loss had a strong positive relationship with $\mathrm{N}$ concentration, which is usual in the early stage of litter decomposition (Berg and Staaf 1980; Berg and Ekbohm 1991), supporting the three-phase model described by Berg and Matzner (1997).

\section{Conclusions}

The present study demonstrated that in $Q$. mongolicadominated temperate deciduous forests, the initial litter qualities, particularly $\mathrm{N}$ and lignin concentrations, decreased with branch age. Mass loss also decreased with age, and branch age had significant effects on the mass loss of branch litter, which was strongly correlated with litter qualities, particularly with $\mathrm{N}$ concentration and $\mathrm{C} / \mathrm{N}$. Differences in branch decomposition by age showed that the age of wood materials was an equally important decomposition factor as wood physical properties, including size, diameter, and length, because branch age affects all the physical characteristics. In our study, the slow decomposition, low $\mathrm{N}$ concentration, and high $\mathrm{N}$ immobilization of branches by age influenced $\mathrm{C}$ and $\mathrm{N}$ cycling in forest ecosystems. Branch litter as fine woody debris has a greater impact on nutrient cycling, because it accounts for approximately $12-22 \%$ of the total litterfall. Although this study focused exclusively on $Q$. mongolica and was conducted under specific temporal and spatial conditions, we suggest that total $\mathrm{N}$ and $\mathrm{C} / \mathrm{N}$ are key factors in the decomposition of woody materials, and that they can be used as predictive indices of branch decomposition in future studies. Further longterm studies are needed to evaluate the effect of age on the decomposition of woody materials and the role of woody debris as a long-term reservoir of $\mathrm{C}$ and $\mathrm{N}$ in temperate deciduous forests.

Acknowledgments This research was supported by the Chung-Ang University Research Scholarship Grants in 2014.

Open Access This article is distributed under the terms of the Creative Commons Attribution 4.0 International License (http:// creativecommons.org/licenses/by/4.0/), which permits unrestricted use, distribution, and reproduction in any medium, provided you give appropriate credit to the original author(s) and the source, provide a link to the Creative Commons license, and indicate if changes were made.

\section{References}

Abbott DT, Crossley DA Jr (1982) Woody litter decomposition following clear-cutting. Ecology 63:35-42

Bao FC, Jiang ZH, Jiang XM, Lu XX, Luo XQ, Zhang SY (2001) Differences in wood properties between juvenile wood and mature wood in 10 species grown in China. Wood Sci Technol 35:363-375

Bargali SS (1996) Weight loss and N release in decomposing wood litter in a eucalypt plantation age series. Soil Biol Biochem 28:699-702

Berg B (1986) Nutrient release from litter and humus in coniferous forest soils-a mini review. Scand J For Res $1: 359-369$

Berg B (2014) Foliar litter decomposition: a conceptual model with focus on pine (Pinus) litter-a genus with global distribution. ISRN For 2014:1-22

Berg B, Ekbohm G (1991) Litter mass-loss rates and decomposition patterns in some needle and leaf litter types. Longterm decomposition in a Scots pine forest VII. Can J Bot 69:1449-1456

Berg B, Matzner E (1997) The effect of N deposition on the mineralization of $\mathrm{C}$ from plant litter and humus. Environ Rev 5:1-25

Berg B, McClaugherty C (2008) Plant litter: Decomposition, humus formation, carbon sequestration, 2nd edn. Springer, Berlin 
Berg B, Staaf H (1980) Decomposition rate and chemical changes of Scots pine needle litter II. Influence of chemical composition. Ecol Bull 32:373-390

Berg B, McClaugherty C, Johansson M (1997) Chemical changes in decomposing plant litter can be systemized with respect to the litter's initial chemical composition. Reports from Departments in Forest ecology and Forest Soils. Swed Univ Agric Sci Rep 74:1-85

Bray JR, Gorham E (1964) Litter production in forests of the world. In: Cragg JB (ed) Advances in ecological research, vol 2. Academic Press, New York, pp 101-157

Bremner JM (1996) Nitrogen-total. In: Sparks DL (ed) Methods of soil analysis. Part 3-chemical methods. SSSA, Madison, pp 1085-1121

Chen X, Wei X, Scherer R (2005) Influence of wildfire and harvest on biomass, carbon pool, and decomposition of large woody debris in forested streams of southern interior British Columbia. For Ecol Manag 208:101-114

Coûteaux MM, Bottner P, Berg B (1995) Litter decomposition, climate and litter quality. Trends Ecol Evol 10:63-66

Dijkstra FA, Hobbie SE, Knops JM, Reich PB (2004) Nitrogen deposition and plant species interact to influence soil carbon stabilization. Ecol Lett 7:1192-1198

Fasth BG, Harmon ME, Sexton J, White P (2011) Decomposition of fine woody debris in a deciduous forest in North Carolina. J Torrey Bot Soc 138:192-206

Fioretto A, Nardo CD, Papa S, Fuggi A (2005) Lignin and cellulose degradation and nitrogen dynamics during decomposition of three leaf litter species in a Mediterranean ecosystem. Soil Biol Biochem 37:1083-1091

Fog K (1988) The effect of added nitrogen on the rate of decomposition of organic matter. Biol Rev 63:433-462

Freedman B, Zelazny V, Beaudette D, Fleming T, Johnson G, Flemming S, Gerrow J, Forbes G, Woodley S (1996) Biodiversity implications of changes in the quantity of dead organic matter in managed forests. Environ Rev 4:238-265

Ganjegunte GK, Condron LM, Clinton PW, Davis MR, Mahieu N (2004) Decomposition and nutrient release from radiata pine (Pinus radiata) coarse woody debris. For Ecol Manag 187:197-211

Garrett LG, Kimberley MO, Oliver GR, Pearce SH, Paul TS (2010) Decomposition of woody debris in managed Pinus radiata plantations in New Zealand. For Ecol Manag 260:1389-1398

Ge X, Zeng L, Xiao W, Huang Z, Geng X, Tan B (2013) Effect of litter substrate quality and soil nutrients on forest litter decomposition: a review. Acta Ecol Sin 33:102-108

Gosz JR, Likens GE, Bormann FH (1972) Nutrient content of litter fall on the Hubbard Brook experimental forest, New Hampshire. Ecology 53:769-784

Gosz JR, Likens GE, Bormann FH (1973) Nutrient release from decomposing leaf and branch litter in the Hubbard Brook Forest, New Hampshire. Ecol Monogr 43:173-191

Harmon ME, Franklin JF, Swanson FJ, Sollins P, Gregory SV, Lattin JD, Anderson NH, Cline SP, Aumen NG, Sedell JR, Lienkaemper GW, Cromack K Jr, Cumminus KW (1986) Ecology of coarse woody debris in temperate ecosystems. Adv Ecol Res 15:133-302

Heal OW, Anderson JM, Swift MJ (1997) Plant litter quality and decomposition: an historical overview. In: Cadisch G,
Giller KE (eds) Driven by nature: plant litter quality and decomposition. CABI Publishing, Wallingford, pp 3-30

Heneghan L, Coleman D, Zou X, Crossley D Jr, Haines B (1999) Soil microarthropod contributions to decomposition dynamics: tropical-temperate comparisons of a single substrate. Ecology 80:1873-1882

Keyser P, Kirk TK, Zeikus JG (1978) Ligninolytic enzyme system of Phanaerochaete chrysosporium: synthesized in the absence of lignin in response to nitrogen starvation. J Bacteriol 135:790-797

Laiho R, Vasander H, Penttilä T, Laine J (2003) Dynamics of plant-mediated organic matter and nutrient cycling following water-level drawdown in boreal peatlands. Global Biogeochem Cycles 17:1053

Li C, Wu C, Duan B, Korpelainen H, Luukkanen O (2009) Agerelated nutrient content and carbon isotope composition in the leaves and branches of Quercus aquifolioides along an altitudinal gradient. Trees 23:1109-1121

Manos PS, Doyle JJ, Nixon KC (1999) Phylogeny, biogeography, and processes of molecular differentiation in Quercus subgenus Quercus (Fagaceae). Mol Phylogenet Evol 12:333-349

Melillo JM, Aber JD, Muratore JF (1982) Nitrogen and lignin control of hardwood leaf litter decomposition dynamics. Ecology 63:621-626

Mun HT (2004) Decay rate and nutrients dynamics during decomposition of oak branches. J Ecol Environ 27:93-98

Nelson DW, Sommers LE (1996) Total carbon, organic carbon, and organic matter. In: Sparks DL (ed) Methods of soil analysis. Part 3-chemical methods. SSSA, Madison, pp 961-1010

Ohshima J, Yokota S, Yoshizawa N, Ona T (2005) Representative heights for assessing whole-tree values and the within-tree variations of derived wood properties in $\mathrm{Eu}$ calyptus camaldulensis and E. globulus. Wood Fiber Sci 37:51-65

Olson JS (1963) Energy storage and the balance of producers and decomposers in ecological systems. Ecology 44:322-331

Ona T, Sonoda T, Itoh K, Shibata M (1997) Relationship of lignin content, lignin monomeric composition and hemicellulose composition in the same trunk sought by their within-tree variations in Eucalyptus camaldulensis and $E$. globulus. Holzforsch. Int J Biol Chem Phys Technol Wood 51:396-404

Osono T, Azuma J, Hirose D (2014) Plant species effect on the decomposition and chemical changes of leaf litter in grassland and pine and oak forest soils. Plant Soil 376:411-421

Parton W, Silver WL, Burke IC, Grassens L, Harmon ME, Currie WS, King JY, Adair EC, Brandt LA, Hart SC (2007) Global-scale similarities in nitrogen release patterns during long-term decomposition. Science 315:361-364

Rowland AP, Roberts JD (1994) Lignin and cellulose fractionation in decomposition studies using acid-detergent fibre methods. Commun Soil Sci Plant Anal 25:269-277

Shin CH, Won HY, Mun HT (2011) Special feature: litter production and nutrient input via litterfall in Quercus mongolica forest at Mt. Worak National Park. J Ecol Environ 34:107-113

Swift MJ, Healey IN, Hibberd JK, Sykes JM, Bampoe V, Nesbitt ME (1976) The decomposition of branch-wood in the 
canopy and floor of a mixed deciduous woodland. Oecologia 26:139-149

Tuomi M, Laiho R, Repo A, Liski J (2011) Wood decomposition model for boreal forests. Ecol Model 222:709-718

Upadhyay VP, Singh JS (1985) Decomposition of woody branch litter on an altitudinal transect in the Himalaya. Vegetatio 64:49-53

Vávřová P, Penttilä T, Laiho R (2009) Decomposition of Scots pine fine woody debris in boreal conditions: implications for estimating carbon pools and fluxes. For Ecol Manag 257:401-412

Yang KC (2001) Classification of major habitats based on the climate conditions and topographic features in Korea. Chung-Ang University, Seoul

Yang FF, Li YL, Zhou GY, Wenigmann KO, Zhang DQ, Wenigmann M, Liu SZ, Zhang QM (2010) Dynamics of coarse woody debris and decomposition rates in an oldgrowth forest in lower tropical China. For Ecol Manag 259:1666-1672

Yatskov M, Harmon ME, Krankina ON (2003) A chronosequence of wood decomposition in the boreal forests of Russia. Can J For Res 33:1211-1226

Yim YJ (1977) Distribution of forest vegetation and climate in the Korean peninsula IV: zonal distribution of forest vegetation in relation to thermal climate. Jpn $\mathrm{J}$ Ecol 27:269-278

Yim YJ, Baik SD (1985) The vegetation of Mt. Seolag: a study of flora and vegetation. The Chung-Ang University Press, Seoul

Zhang YT (2000) Fagaceae. In: Fu LK, Chen TQ, Lang KY, Hong T, Lin Q (eds) Higher plants of China. Qingdao Publishing House, Qingdao, pp 177-254 